\title{
Puberty in male collared peccary (Pecari tajacu) determined by quantitative analysis of spermatogenic cells
}

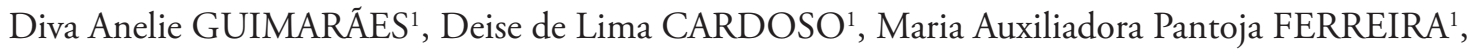 \\ Natália Inagaki de ALBUQUERQUE²
}

\begin{abstract}
Biological studies are necessary for the management of wildlife in captivity, and knowledge of reproduction is one of the important features for increasing production. The objective of the research was to determine the age at which male collared peccaries reach puberty. Testicular samples of 15 animals, aged 7 to 16 months, distributed into five groups (G1, G2, G3, G4 and G5) were used. The testes showed considerably increased weight, length and width $(p<0.05)$ from G1 to G3, whereas, from this group onward, the development of this organ was slower. There was positive correlation $(\mathrm{p}<0.001)$ between the following testicular parameters: weight and length $(r=0.97)$, weight and width $(r=0.88)$, length and width $(r=0.92)$. Regarding the diameter of seminiferous tubules, an increase was observed ( $p<0.05)$ from G1 to G4. The total number of spermatogenic cells increased significantly $(\mathrm{p}<0.05)$ until G3 and then it stabilized. There was also positive correlation between testis weight and tubular diameter $(r=0.99, p<0.001)$, and testis weight and spermatogenic cells $(r=0.98, p<0.001)$. The number of Sertoli cells decreased significantly $(\mathrm{p}<0.05)$ from G1, when they were undifferentiated as support cells, to G5, when they occurred together with the complete line of spermatic cells. The results demonstrate that the reproductive development of peccaries can be classified into the following stages: impuberty (G1, 7-8 months); pre-pubertal (G2, 9-10 months); pubertal (G3, 11-12 months); post-pubertal 1 (G4, 13-14 months); and post-pubertal 2 (G5, 15-16 months). Based on the histological analyses, puberty in the male collared peccary was determined to occur between 11 and 12 months of age.
\end{abstract}

KEYWORDS: reproduction; testicles; spermatogenesis, Tayassuidae.

\section{Puberdade em macho de cateto (Pecari tajacu) determinada pela análise quantitativa das células espermatogênicas}

\begin{abstract}
RESUMO
Estudos biológicos são necessários para o manejo da vida silvestre em cativeiro, e o conhecimento da reprodução é um dos aspectos importantes para o aumento da produção. Esta pesquisa teve como objetivo determinar a idade da puberdade do cateto macho. Foram utilizadas amostras testiculares de 15 animais, entre 7 a 16 meses, distribuídos em cinco grupos (G1, G2, G3, G4 e G5). Os testículos aumentaram no peso, comprimento e largura consideravelmente ( $p<0,05)$ do G1 ao G3, enquanto que, a partir deste grupo, o desenvolvimento desse órgão foi mais lento. Houve correlação positiva $(\mathrm{p}<0,001)$ entre os seguintes parâmetros testiculares: peso e comprimento $(r=0,97)$, peso e largura $(r=0,88)$, comprimento e largura $(r=0,92)$. Com relação ao diâmetro tubular, observou-se um aumento $(\mathrm{p}<0,05)$ do G1 ao G4. A quantidade total de células espermatogênicas aumentou significativamente $(\mathrm{p}<0,05)$ até o $\mathrm{G} 3$, e se estabilizou a partir deste grupo. Houve correlação positiva entre o peso testicular e o diâmetro tubular $(r=0,99, \mathrm{p}<0,001)$, bem como o peso testicular e as células espermatogênicas $(r=0,98, \mathrm{p}<$ $0,001)$. A quantidade de células de Sertoli reduziu significativamente $(p<0,05)$ do $G 1$, onde se encontravam indiferenciadas como células de suporte, até G5, onde foram observadas juntamente com todas as células da linhagem espermática. Estes resultados demonstraram que as fases do desenvolvimento reprodutivo de catetos podem ser classificadas em: impúbere (G1, 7-8 meses), pré-púbere (G2, 9-10 meses), púbere (G3,11-12 meses), pós-púbere 1 (G4, 13-14 meses) e pós-púbere 2 (G5, 15-16 meses). Com base na análise histológica, a puberdade dos catetos machos ocorre entre 11 e 12 meses de idade.
\end{abstract}

PALAVRAS-CHAVE: reprodução, testículos, espermatogênese, Tayassuidae.

1 Instituto de Ciências Biológicas, Universidade Federal do Pará, Rua Augusto Corrêa, nº1, Guamá, CEP 66075-110, Belém-Pará, Brazil; Emails: diva@ufpa.br, deisecardosomv@yahoo.com.br, auxi@ufpa.br;

2 Empresa Brasileira de Pesquisa Agropecuária, Embrapa Amazônia Oriental, Travessa Dr. Enéas Pinheiro s/nº CEP 66095-100, Belém-Pará, Brazil; natalia.albuquerque@embrapa.br 


\section{INTRODUCTION}

Among the most hunted species in the Amazon region are the tayassuidae, particularly the species Pecari tajacu, whose reproductive biology is still little known. Knowledge of reproductive biology is important in establishing programs for the conservation and production in situ and ex situ of wildlife (Andrabi and Maxwell 2007; Fickel et al. 2007). One of the strategies to attain this knowledge is the studying the attainment of puberty in the animal to obtain valuable information for proper reproductive management practices, the selection of individuals, increase in productivity and efficiency, and for genetic improvement (Guimarães et al. 2009). In males, puberty is associated with the beginning of spermatogenesis.

Some studies of the reproductive physiology of the male collared peccary, Pecari tajacu, were performed by Hellgren et al. (1989), Costa et al. (2010), and Kahwage et al. (2010). They analyzed andrological parameters such as the levels of testosterone, testis morphology, spermatogenesis, and the quality of semen.

Spermatogenesis in the collared peccary was investigated by Costa et al. (2004). Morphological aspects and the stages of the seminiferous epithelium cycle in adult animals were found to be similar to that of swine (Sus scrofa domesticus). Costa et al. (2010) observed that the seminiferous epithelium cycle of the collared peccary lasts $12.3 \pm 0.2$ days, and that the complete spermatogenic process lasts $55.1 \pm 0.7$ days, with a sperm production per gram of testis of approximately $23.4 \pm 2 \times 10^{6}$, which is similar to that of swine and wild boar (Sus scrofa).

Studying spermatogenesis during the growth phase allows for establishment of the pubertal period and defines the moment when the animal enters the reproductive phase, as this is consequently the most favorable period for its management in captivity. The goal of the present work was to determine the age at which male collared peccary reach puberty.

\section{MATERIALS AND METHODS}

The scientific breeding center for collared peccaries at Embrapa Amazônia Oriental (Belém, Pará, Brazil) provided 15 animals for this study. The animals were born in captivity, raised in family groups in $36 \mathrm{~m}^{2}$ paddocks and fed with commercial pig finisher ration (energy content $2500 \mathrm{kcal}$ per $\mathrm{kg}$ and $14 \%$ crude protein). They were assigned to the following age groups: G1 (7-8 months of age), G2 (9-10 months of age), G3 (11-12 months of age), G4 (13-14 months of age), and G5 (15-16 months of age). Each group consisted of three individuals.

When the animals reached the assigned age, they were anesthetized with ketamine chloridate $\left(5 \mathrm{mg} \mathrm{kg}^{-1}\right)$ and
$0.2 \%$ acepromazine $\left(0.2 \mathrm{mg} \mathrm{kg}^{-1}\right)$, and subjected to bilateral orchiectomy. The experiments performed in this study were approved by the Ethical Committee for Animal Research, Universidade Federal do Pará (Authorization number CEPAEZOO001-08), and were conducted in compliance with current Brazilian and international laws on the manipulation of animals for research purposes.

Testis length and width were measured with digital calipers, while its weight was determined with an analytical balance. Testis fragments were fixed in ALFAC $(85 \mathrm{~mL}$ of $80 \%$ ethyl alcohol, $10 \mathrm{~mL}$ of $40 \%$ formaldehyde, and 5 $\mathrm{mL}$ of glacial acetic acid) for 24 hours before commencing histological processing for paraffin embedding. Next, thick histological sections $(5 \mu \mathrm{m})$ were obtained and dyed with a solution of hematoxylin-eosin and analyzed in a light microscope (Olympus CH30, Japan).

The diameters of 10 and 20 seminiferous tubules were measured in those animals presenting complete and incomplete spermatogenesis respectively, using a micrometric eyepiece mounted on the objective used.

Spermatogenic cells and Sertoli cells were quantified for each age group. The number of cells of each type was counted in cross sections of seminiferous tubules and corrected according to Abercrombie (1946) and modified by Amann (1962). Cell measurements and quantitative analysis were performed using the tubular morphology method proposed by Courot et al. (1970).

Descriptive and inferential statistical methods were applied. A significance level of $\alpha=0.05$ was adopted for hypothesis testing of the data, to quantify spermatogenic cells and tubule diameter. Analysis of variance one-way ANOVA followed by post hoc Student's t-test was used to evaluate the differences between the growth phases. Pearson's co-efficient was used to estimate the linear correlation between the pair of the following variables: age and testis weight, testis biometry (weight and length, weight and width, length and width), testis weight; and tubule diameter; testis weight and spermatogenic cells. Statistical analysis was done using BioEstat (Ayres et al. 2007).

\section{RESULTS}

Testis weight, length, width, and tubule diameter data are described according to age group in Table 1 . There was a constant and gradual increase $(\mathrm{p}<0.05)$ in values for these age groups.

Testis weight increased from G1 to G3 ( $<<0.05$ ), becoming less, still significant $(p<0.05)$, until G5. Testis length and width increased sharply until G3 ( $p<0.05)$, then slowed from G4 on $(\mathrm{p}<0.05)$.

Testis age and weight $(\mathrm{r}=0.95)$, weight and length $(\mathrm{r}=$ $0.97)$, weight and width $(\mathrm{r}=0.88)$, and length and width ( $\mathrm{r}$ $=0.92)$ were positively correlated $(\mathrm{p}<0.001)$. 
Table 1 - Testicular parameters (weight, length, width) and testicular diameter (mean \pm standard deviation) of collared peccary, of different age groups.

\begin{tabular}{lccccc}
\hline & \multicolumn{5}{c}{ Groups (months of age) } \\
\cline { 2 - 6 } & G1 (7-8) & G2 (9-10) & G3 (11-12) & G4 (13-14) & G5 (15-16) \\
\hline $\mathrm{Tg}(\mathrm{g})$ & $2.9 \pm 0.2^{\mathrm{e}}$ & $6.0 \pm 2.1^{\mathrm{d}}$ & $15.7 \pm 1.0^{\mathrm{c}}$ & $18.1 \pm 0.5^{\mathrm{b}}$ & $19.3 \pm 0.8^{\mathrm{a}}$ \\
$\mathrm{Tl}(\mathrm{mm})$ & $23.5 \pm 0.6^{\mathrm{e}}$ & $29.4 \pm 2.3^{\mathrm{d}}$ & $38.7 \pm 2.5^{\mathrm{c}}$ & $40.2 \pm 1.1^{\mathrm{b}}$ & $42.9^{\mathrm{a}} \pm 3.2^{\mathrm{a}}$ \\
$\mathrm{Td}(\mathrm{mm})$ & $14.9 \pm 0.6^{\mathrm{e}}$ & $18.6 \pm 1.6^{\mathrm{d}}$ & $22.8 \pm 3.2^{\mathrm{c}}$ & $23.2 \pm 3.1^{\mathrm{b}}$ & $26.3 \pm 1.9^{\mathrm{a}}$ \\
$\mathrm{Dt}(\mu \mathrm{m})$ & $70.3 \pm 3.4^{\mathrm{d}}$ & $102.6 \pm 10.0^{\mathrm{c}}$ & $166.9 \pm 9.9^{\mathrm{b}}$ & $180.0 \pm 7.6^{\mathrm{a}}$ & $196.8 \pm 6.7^{\mathrm{a}}$ \\
\hline
\end{tabular}

Different superscript letters in same line indicate difference (one-way ANOVA post hoc Student's t-test, $p<0.05$ ); Tg- Testicular weight; TI- Testicular length; Td- Testicular width; Dt- Diameter of tube.

Table 1 shows that the tubule diameter increased $(\mathrm{p}<$ 0.05 ) from G1 to G4, and the difference between G4 and G5 was not significant $(p>0.05)$. However, correlation between testis weight and tubule diameter was significant $(\mathrm{r}$ $=0.99, \mathrm{p}<0.001)$.

The total spermatogenic cell count increased significantly $(\mathrm{p}<0.05)$ until G3, with a more gradual increase in the spermatogenic activity being observed between G1 and G2, with an increase and stabilization observed in G3 (Table 2). The correlation between spermatogenic cells and testis weight was significant $(r=0.98, p<0.001)$, with a progressive increase observed in these parameters with animal age (Table 1 and Table 2).

The number of Sertoli cells decreased significantly $(\mathrm{p}<$ 0.05 ) from G1, when they were undifferentiated as support cells, to G5, when they were observed together with the complete line of spermatic cells (Table 2).

Microscopic analysis revealed maturing germinative epithelium in G1 and seminiferous tubules without lumen. This epithelium was supported by a basal layer on top of fusiform cells. Connective tissue with rounded cells was visible between the tubules (Figure 1A). In G2, the seminiferous tubules presented lumen, and the germinative epithelium consisted of spermatogenic cells in various phases of maturation. The spermatogonia, primary spermatocytes and Sertoli cells are shown in figure 1B. In G3, the seminiferous tubules were well-defined, with the complete line of spermatic and Sertoli cells (Figures 1C, 1D). In G4, increased numbers of spermatogenic cells and of spermatozoa were frequent in the tubule lumen (Figure 2A). G5 did not present an increase in the number of cells, demonstrating stability of the epithelium (Figure 2B).

These results show that the phases of reproductive development of the male collared peccary can be classified as follows: impuberty (G1, 7-8 months), pre-puberal (G2, 9-10 months), puberal (G3, 11-12 months), post-puberal 1 (G4, 13-14 months), and post-puberal 2 (G5, 15-16 months).

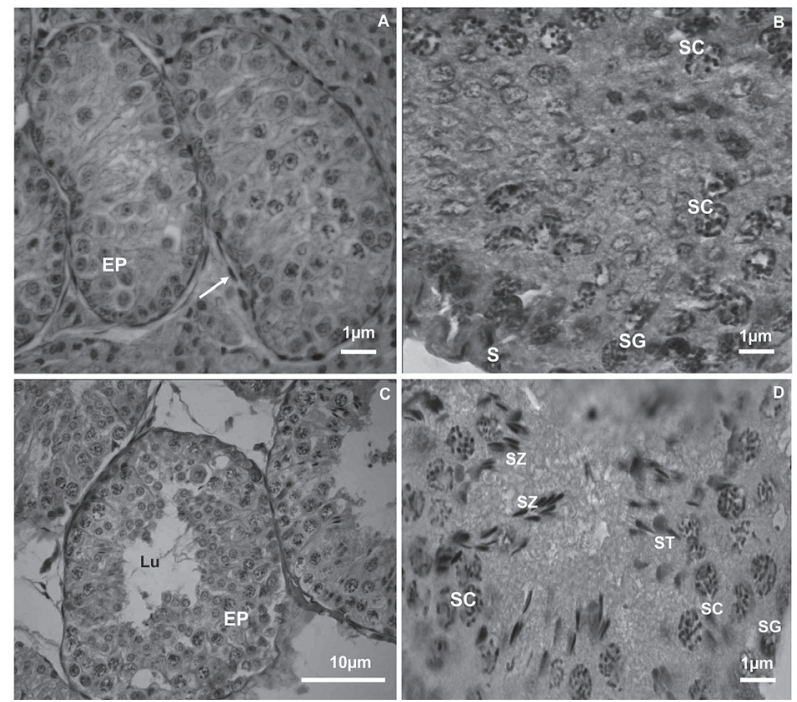

Figure 1 - Photomicrograph of seminiferous tubule of the impuberal and puberal collared peccary. H\&E. (A) 8 months- Germinative Epithelium (EP), Fusiform cells (white arrow) 1000X. (B) 9 months- Spermatogonia (SG), Spermatocytes (SC), Sertoli cells (S), 1000X. (C) 12 months- Germinative Epithelium (EP), Lumen (Lu), 400X. (D) 12 months- Spermatogonia (SG), Spermatocytes (SC), Spermatids (ST), Spermatozoa (SZ), 1000X.

Table 2 - Number of cells per cross-sections of seminiferous tubules (mean \pm standard deviation) of collared peccary, of different age groups.

\begin{tabular}{cccccc}
\hline & \multicolumn{5}{c}{ Groups (months of age) } \\
\cline { 2 - 6 } & G1 (7-8) & G2 (9-10) & G3 (11-12) & G4 (13-14) & G5 (15-16) \\
\hline SG & $0.88 \pm 0.04^{\mathrm{b}}$ & $0.98 \pm 0.03^{\mathrm{a}}$ & $1.02 \pm 0.07^{\mathrm{a}}$ & $1.01 \pm 0.05^{\mathrm{a}}$ & $1.05 \pm 0.01^{\mathrm{a}}$ \\
PL/L & --- & $19.72 \pm 1.03^{\mathrm{b}}$ & $23.65 \pm 0.56^{\mathrm{a}}$ & $24.64 \pm 0.28^{\mathrm{a}}$ & $25.06 \pm 0.43^{\mathrm{a}}$ \\
OS & --- & --- & $16.66 \pm 0.46^{\mathrm{b}}$ & $17.97 \pm 0.52^{\mathrm{b}}$ & $21.70 \pm 2.22^{\mathrm{a}}$ \\
RS & --- & --- & $65.85 \pm 0.33^{\mathrm{c}}$ & $69.29 \pm 0.38^{\mathrm{b}}$ & $70.86 \pm 1.02^{\mathrm{a}}$ \\
Sp & $0.88 \pm 0.04^{\mathrm{c}}$ & $11.10 \pm 9.59^{\mathrm{b}}$ & $26.79 \pm 25.06^{\mathrm{a}}$ & $28.23 \pm 26.35^{\mathrm{a}}$ & $29.67 \pm 26.65^{\mathrm{a}}$ \\
S & $15.24 \pm 0.55^{\mathrm{a}}$ & $13.82 \pm 0.28^{\mathrm{b}}$ & $9.96 \pm 0.6^{\mathrm{c}}$ & $8.63 \pm 0.27^{\mathrm{d}}$ & $7.45 \pm 0.18^{\mathrm{e}}$ \\
\hline
\end{tabular}

Different letters in same line indicate difference (one-way ANOVA post hoc Student's t-Test, $p<0.05$ ). Spermatogonia (SG); Spermatocytes pre-leptotene/leptotene (PL/L); Pachytene Spermatocytes (PS); Round Spermatids (RS); all types of Spermatogenic Cells (Sp), Sertoli Cells (S). 

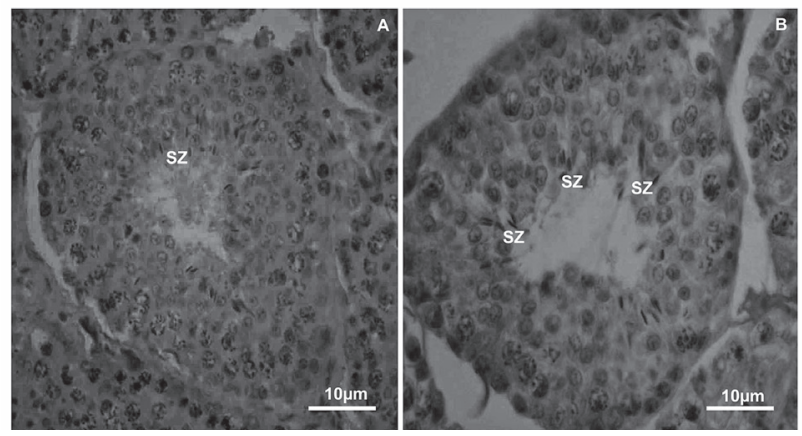

Figure 2 - Photomicrograph of seminiferous tubule of the postpuberal collared peccary. H\&E. (A) 13 months- Seminiferous tubules with lumen and spermatozoa (SZ), 400X. (B) 15 months- Presence of spermatozoa in the tubule lumen, $400 \mathrm{X}$.

\section{DISCUSSION}

Biometric parameters of the testis are some of the factors used to determine the reproductive development of mammals (Brito et al. 2004). These parameters (testis volume, weight, length, width, and scrotum circumference) vary with the race, season, age, and body weight, among other factors (Forgaty et al. 1980; Bongso et al. 1982).

The testis parameters of the collared peccary (weight, length, width) increased as the animals aged. A positive correlation was observed between the testis weight and the length, width, tubule diameter, and the number of spermatogenic cells, which corroborates findings for other mammals like Sus scrofa domesticus (França 1987; França et al. 2000), Bubalis bubalis (Melo 1991; Ohashi 1993; Ohashi et al. 2007), Capra hircus (Becker-Silva 2000), and the Tayassu pecari (Sonner et al. 2004).

The formation of the lumen of seminiferous tubules in the collared peccary starts at ten months of age, differing from the Yorkshire swine and from the Piau swine in which it starts respectively, at two months of age (Godinho and Cardoso 1979), and from the Piau swine, and between months three and five (França 1987). According to Bressler (1978), the tubule lumen formation is related to the level of testosterone, and its commencement is indicated by a variation in the hormone's level in different species.

Spermatogenesis starts in collared peccary at 11 months old. Spermatozoa were observed in the tubule lumen, which, according to Courot et al. (1970), confirms the onset of puberty based on histological aspects. This phase was probably preceded by an increase in the follicle-stimulating hormone (FSH), which potentiated the development of receptors of the luteinizing hormone (LH) in the testis. This increased the secretion of testosterone, whose action is essential for the maturation of the cells of the testis parenchyma (Hughes and Varley 1984).
In collared peccary, the mean number of spermatogonia A was similar to that found in the Yorkshire and Piau swine (França 1987, 1991), and greater than that observed in whitelipped peccaries (Costa et al. 2007). The mean number of spermatocytes I in pre-leptotene/leptotene and pachytene was smaller in Piau (França 1987) and greater in wild boar (Murta et al. 2008). The mean number of spermatids in the collared peccary was smaller than that in swine (Godinho and Cardoso 1979; França 1987) and of white-lipped peccaries (Costa et al. 2007), and higher in wild boar (Murta et al. 2008). The mean number of spermatic cells in the puberal collared peccary was close to that observed in the adult collared peccary (Costa $e t$ al. 2004) and in wild boar (Murta et al. 2008).

In the collared peccary, it was observed that the number of Sertoli cells decreased from impuberty to the puberal phases, which can be explained by the growth of the testis with the elongation of the seminiferous tubules and the consequent distribution of these cells along the tubule. This fact reinforces the proposition of Courot et al. (1970) that the mitotic activity of undifferentiated support cells induces the increase in the number of cells until spermatogenesis, when this division stops and larger Sertoli cells are formed with cytoplasm expansion along the seminiferous tubule.

Based on histological aspects, the puberty of the male collared peccary occurs between 11 and 12 months of age. These results are important to expand the knowledge of the reproductive morphology of this species and thus improve its production management and conservation.

\section{ACKNOWLEDGEMENTS}

We extend our sincere thanks to Coordenaçáo de Aperfeiçoamento de Pessoal de Nível Superior (Project 130/07-DGU/CAPES Foundation) for supporting this project. The authors thank Gail Young for assistance with the helpful comments.

\section{REFERENCES}

Andrabi, S.M.H.; Maxwell, W.M.C. 2007. A review on reproductive biotechnologies for conservation of endangered mammalian species. Animal Reproduction Science, 99:223-243.

Abercrombie, M. 1946. Estimation of nuclear population from microtome sections. Anatomical Record, 49:238-248.

Amann, R.P. 1962. Reproductive capacity of dairy bulls - IV Spermatogenesis and testicular germ cell degeneration. The American Journal of Anatomy, 110:69-78.

Ayres, M.; Ayres Jr., M.; Ayres, D.; Santos, A.A. 2007. Bioestat 5.0: Aplicaçôes estatísticas nas áreas das ciências biológicas e médicas. Sociedade Civil Mamirauá, MCT-CNPq, Belém, Brazil. 364 p.

Becker-Silva, S.C. 2000. Caracterização histológica e seminal do desenvolvimento sexual de caprinos Saanen, criados em sistema 
intensivo. MSc Thesis, Federal University of Minas Gerais, Belo Horizonte, Brazil. 177p.

Bongso, T.A.; Jainudeen, M.R.; Sitizhran, A.S. 1982. Relationship of scrotal circumference to age, body weight and onset of spermatogenesis in goats. Theriogenology, 18:513-524.

Bressler, R.S. 1978. Hormonal control of postnatal maturation of the seminiferous cord. Annales de Biologie Animale Biochimie Biophysique, 8:535-540.

Brito L.F.; Silva A.E.; Unanian, M.M.; Dode, M.A.; Barbosa, R.T.; Kastelic, J.P. 2004. Sexual development in early and late maturing Bos indicus and Bos indicus $\mathrm{x}$ Bos taurus crossbred bulls in Brazil. Theriogenology, 62:1198-1217.

Costa, D.S.; Henry, M.; Paula, T.A.R. 2004. Espermatogênese em catetos (Tayassu tajacu). Arquivo Brasileiro de Medicina Veterinária e Zootecnia, 56:46-51.

Costa D.S.; Menezes; C.M.C.; Paula, T.A.R. 2007. Spermatogenesis in white-lipped peccaries (Tayassu pecari). Animal Reproduction Science, 98:322-334.

Costa, G.M.J.; Leal, M.C.; Silva, J.V.; Ferreira, A.C.S.; Guimarães, D.A.A.; França, L.R. 2010. Spermatogenic cycle length and sperm production in a feral pig species (collared peccary, Tayassu tajacu). Journal of Andrology, 31:221-230.

Courot, M.; Hochereau-De-Reviers, M.T.; Ortavant, R. 1970. Spermatogenesis, p. 339-432. In: Johnson, A.D.; Gomes, W.R.; Vandemark, N.L. (Eds.). The testis. Academic Press, New York, USA.

Fickel J.; Wagcher, A.; Ludwig, A. 2007. Semen cryopreservation and the conservation of endangered species. European Journal of Wildlife Research, 53:81-89.

Godinho, H.P.; Cardoso, F.M. 1979. Desenvolvimento sexual de porcos Yorkshire.II. Estabelecimento e evolução da espermatogênese. Arquivos da Escola Veterinária da Universidade Federal de Minas Gerais, 31:351-361.

França, L.R. 1987. Desenvolvimento testicular de suinos da raça Piau, do nascimento aos 12 meses de idade. MSc Thesis, Federal University of Minas Gerais, Belo Horizonte, Brazil. 79p.

França, L.R. 1991. Análise morfofuncional da espermatogênese de suinos adultos da raça Piau. Ph.D. Thesis, Federal University of Minas Gerais, Belo Horizonte, Brazil. 15p.

França, L.R.; Silva, J.R.; Chiarini-Garcia, H.; Garcia, S.K.; Debelju, K. 2000. Cell proliferation and hormone changes during postnatal development of the testis in the pig. Biology of Reproduction, 63:1629-1636.
Fogarty, N.M.; Lunstra, D.D.; Young, L.D.; Dickerson, G.E. 1980. Breed effects and heritability of testis measurements in sheep. Journal of Animal Science, 51:117.

Guimarães D.A.; Ramos, R.S.; Garcia, G.W.; Ohashi, O.M. 2009. The stimulatory effect of male agouti (Dasyprocta prymnolopha) on the onset of female puberty. Acta Amazonica, 39:759-762.

Hellgren, E.C.; Lochmiller, R.; Amoss, M.S.; Seager, S.W.; Magyar, S.J. 1989. Seasonal variationin serun testosterona testicular measurements and semen characteristics in the collared peccary (Tayassu tajacu). Journal of Reproduction and Fertility, 85:677686.

Hughes, P.E.; Varley M.A. 1984. Reproducción del cerdo. Acribia, Zaragoza, Spain. 253p.

Kahwage, P.; Garcia, A.R.; Guimarães, D.A.A.; Ohashi, O.M.; LuzRamos, R.S.; Dias, H.L.T.; Albuquerque, N.I.; Bartha, M.M. 2010. Biometria testicular, eletroejaculação e características seminais de caititus, Tayassu tajacu Linnaeus, 1758 (Mammalia, Artiodactyla, Tayassuidae) mantidos em cativeiro na Amazônia Oriental. Acta Amazonica, 40:771-778.

Melo, M.I.V. 1991. Desenvolvimento testicular e dinâmica da espermatogênese de búfalos mestiços de 10 a 24 meses de idade. MSc Thesis, Federal University of Minas Gerais, Belo Horizonte, Brazil. 66p.

Murta, D.V.F.; Costa, D.S.; Rodrigues, W.R. 2008. Rendimento intrínseco da espermatogênese durante o período púbere e póspúbere em javalis (Sus scrofa scrofa). In: $35^{\circ}$ Brazilian Congress of Veterinary Medicine, Gramado, Rio Grande do Sul, Brazil.

Ohashi, M.O. 1993. Estudo morfofisiológico do testículo de búfalos mestiços (B. bubalis) em diferentes idades. Ph.D. Thesis, Universidade Estadual Paulista, Botucatu, São Paulo, Brazil. $111 \mathrm{p}$.

Ohashi, O.M.; Miranda, M.S.; Cordeiro, M.S.; Santos, S.D. 2007. Desenvolvimento reprodutivo do macho bubalino: circunferência escrotal, atividade espermática e endocrinologia. Revista Brasileira de Reprodução Animal, 31:299-306.

Sonner, J.B.; Miglino, M.A.; Santos, T.C.; Carvalhal, R.; Nero, A.C.; Moura, C.E.B.; Oliveira, M.F. 2004. Aspectos macroscópicos e morfométricos dos testículos em catitus e queixadas. Biota Neotropica, 4:1-13.

Recebido em: 16-11-2011

Aceito em: 26-01-2012 
